\title{
ARBUSCULAR MYCORRHIZAL FUNGI AND SOIL AGGREGATION
}

\author{
Fernando Borie, Rosa Rubio, Alfredo Morales
}

Universidad de La Frontera. Casilla 54-D-Temuco. Corresponding author: fborie@ufro.cl

\section{Hongos micorrícicos arbusculares y agregación de suelo}

Keywords: arbuscular mycorrhizal fungi, soil aggregates, glomalin.

\begin{abstract}
Soil aggregation is governed by several biotic and abiotic components including landuse management. Aggregation is essential to maintain soil physical properties and facilitate biogeochemical cycling. Hyphae of arbuscular mycorrhizal fungi (AMF) are considered to be primary soil aggregators and there is a positively correlation between AMF hyphae and aggregate stability in natural systems. Recent evidence suggests that glomalin (GRSP), a glycoprotein produced by AMF hyphae which has a cementing capacity to maintain soil particles together, is mainly involved in such aggregation. However, recently controversial results together with reported shortcoming in glomalin determinat suggest to proceed with caution when studying glomalin in connection with soil aggregation. Relationships between glomalin and soil aggregates found in Chilean soils are discussed.
\end{abstract}


Palabras Claves: Hongos micorrícicos, agregados de suelo, glomalina.

\section{RESUMEN}

La agregación de suelo es gobernada por una serie de factores bióticos y abióticos incluyendo el manejo del suelo. La agregación es fundamental para mantener las propiedades físicas del suelo y facilitar los ciclos biogeoquímicos. Las hifas de los hongos formadores de micorrizas arbusculares (MA) son consideradas como importantes agentes aglutinadores de partículas del suelo y se han descrito correlaciones positivas entre hifas de hongos MA y estabilidad de agregados en sistemas naturales. Recientemente existen evidencias que sugieren que la glomalina (GRSP), una glicoproteína producida en gran cantidad por las hifas de los hongos MA y que tiene una capacidad cementante de las partículas de suelo, está fuertemente involucrada en dicha agregación. Sin embargo, resultados contradictorios obtenidos recientemente junto con problemas reportadas en la determinación de glomalina sugieren proceder con cautela cuando se relaciona la glomalina con respecto a la agregación del suelo. Se discuten interrelaciones encontradas en suelos chilenos entre glomalina y agregados del suelo.

\section{INTRODUCTION}

Soil structure exerts important influences on the functioning of soil, its ability to support plant and animal life, controlling environmental quality with especial emphasis on soil $\mathrm{C}$ sequestration, nutrient and gas fluxes and water quality. Soil structure is often expressed as the degree of stability of aggregates being a major factor which moderates physical, chemical, and biological processes leading the soil dynamics (Bronick and Lal, 2005). Soil aggregates results from a combination of primary mineral particles with organic and inorganic materials. This process, dynamic and complex, is influenced in turn by the interaction of several factors including environmental components, soil management, plant effects but largely by soil properties. Among these the most significant are moisture availability, mineral composition, soil texture, the quantity and quality of SOM, microbial and enzyme activities, mineral nutrients and others such as polycations, etc. Soil aggregation, begins with the consolidation of soil particles into microaggregates $(<250 \mu \mathrm{m})$ and further formation of macroaggregates $(>250 \mu \mathrm{m})$.

The mechanism involved in soil aggregation is complex but in general is viewed as microaggregates being formed from organic molecules tied to clay and polycations, which in turn are linked with other microaggregates to form macroaggregates. Briefly, aggregation is the result of rearrangement, flocculation and cementation of soil particles where soil organic carbon, polycations, clay, minerals and, especially biota are playing a key role. Here, we will describe shortly the principal factors involved in soil aggregates formation with specially attention to the soil components involved in plant growth and microbial development. Readers who want to deep in this topic may read some interesting recent reviews (Bronick and Lal, 2005; Rillig and Mummey, 2006) and other specific papers related to soil structure (Six et al., 1999; 2000). 


\section{Soil properties contributing to soils aggregation}

\section{Soil organic carbon fraction}

Soil organic carbon produces some heterogeneous habitats where aggregation is more intense. The wide variety on chemical nature of soil organic compounds determines its formation and decomposition rates which induce transient or prolonged effects. However, all factors for soil aggregates formation are directly or indirectly related in this process (Chenu et al., 2000). Therefore, the effect on aggregation of labile sources of organic C is transient whereas $\mathrm{C}$ sources with higher stability increase the permanence of such effect (Schulten and Leinweber, 2000). Humic substances are believed to be recalcitrant as a result of their chemical resistance and their interactions with clays and inorganic soil components conferring physical protection against microbial degradation. For instance, Chorover et al. (2004) studying a weathering chronosequence of volcanic soils in Hawaii found that aliphatic and aromatic components of organic matter dominate humic acids in later stages of soil development (from 150-400 ky). This observation is in contrast to wet chemical analysis showing that lignin, the most important aromatic compounds of soils may remain in soil only for 100 years (Dignac et al., 2005). Thus, it may be concluded that the wet chemical techniques to typify soil organic matter extracted from volcanic soils is not significant because chemical fractionation of SOM using alkaline removal does not yield a biological functional fraction of soils (Oades, 1988). In spite of this, the classical concept of aggregation is still being used. The coating of particles with such recalcitrant materials including humic and fulvic acids and humins contribute to maintain particles together avoiding degradation processes. These types of organic compounds are very important in organic soils where the bulk of organic carbon is mainly constituted by humic substances (Aguilera et al., 1997).

On the other hand, particulate organic matter (POM) constituted by large particles of organic matter $(250-2000 \mu \mathrm{m})$ as a light fraction, can be considered as free or overlayed organic matter on soil particles which in turn they offer a higher physical protection against decomposition of POM. Particulate organic matter may be an important factor in the formation of macroaggregates throughout direct binding action over microaggregates or indirectly through the polysaccharides produced by microorganisms when metabolizing POM (Jastrow, 1996).

Other important sources of organic compounds on aggregation are polysaccharides, carbohydrates, lignin and lipids. Therefore, the role played by carbohydrates is variable depending on its source and nature being more resistant to decomposition those produced by microorganisms (Bronick and Lal, 2005). Polysaccharides have a transient effect functioning as bridges to bind soil particles or sometimes acting as glue for maintaining particles together. Chemical nature of lignin together with its high recalcitrance, even when its biological stability have been questioned to be no more than $100 \mathrm{yr}$ (Dignac et al., 2005) suggest a very low direct effect on aggregation; however, in our experience, where it is common to find lignin decomposers, the fungal mycelia favor the aggregation through hyphal network. Lipids, as a cell wall constituent is found in small amounts in soils (Borie and Barea, 1985), having possibly a very transient effect.

Finally, in recent years it has been described the isolation from soil of a glycoprotein produced by arbuscular mycorrhizal fungi with a strong cementing capacity of soil particles (Wright and Upadhyaya, 1996; 1998; Rillig et al., 2002; Rillig 2004). However, due to the high importance this compound presents it will be described in further paragraphs. 


\section{Polycations}

Polyvalent cations such as $\mathrm{Al}$ and $\mathrm{Fe}$ habitually found in acidic soils improve soil aggregation through bridges formation between inorganic minerals or clay and soil organic carbon. Aggregates containing clays and $\mathrm{Al}$ and $\mathrm{Fe}$ oxides or hydroxides promote soil organic $\mathrm{C}$ incorporation conferring aggregate stability, especially in volcanic soils. Recently, Matus et al. (2006) have demonstrated that soil organic matter accumulation in Chilean volcanic soils is produced by $\mathrm{Al}$ stabilization rather than climatic conditions and clay content of soils. Bivalent cations such as $\mathrm{Ca}$ and $\mathrm{Mg}$ also improve soil aggregation in the same way as trivalent cations above mentioned. However, in some soils $\mathrm{Mg}$ may have a deleterious effect on aggregation due to a higher swelling effect on clays present in such soils (Zhang and Norton, 2002). Consequently, the use of soil amendments such as lime, gypsum or dolomite can have significant effects on soil aggregates formation.

\section{Clay minerals}

Clay minerals influence properties affecting soil aggregation. As clay interacts with soil organic carbon and both are intimately related with aggregates, all soil properties affecting one also affect to the other and soil aggregation as a whole. Thus, $\mathrm{pH}, \mathrm{CEC}$, ions and the nature of mineralogy influence soil aggregation. In general, aggregation is high in high-activity clays (for instance, doubled layered crystal structure), and soil organic carbon is associated to high CEC. Non-crystalline clay minerals such as allophane and imogolite, both typic from Chilean volcanic derived soils, with high variable charge tend to produce high aggregation. Clay type also affect decomposition rate of soil organic carbon.

\section{Biota}

There is consensus that among soil biota, fungi are the most important agents involved in soil aggregation through fungal mycelia network, although roots and bacteria have a significant role as well (Degens, 1997; Tisdall et al., 1997). The role of fungi in soil aggregation can be indirect (or passive) due to a physical network of hyphae maintaining soil particles together or directly (active) by cementing capacity of the extracellular compounds released. Among this, arbuscular mycorrhizal fungi (AMF) appear to play a predominant effect on aggregates formation because the symbiosis significantly changes the root functioning. They also have a vast and more extensive hyphal mycelia in comparison with saprobic fungi. In addition, it is known that plant species may differ in their effects on soil aggregation, in agricultural soils as well as in natural ecosystems (Eviner and Chapin, 2002; Pietrowski et al., 2004) and, consequently, changes in plant community are also affecting soil structure. However, as AMF diversity affects plant community composition soil aggregated in turn will be influenced (van der Heijden et al., 1998). In summary, any event affecting both root development and AMF behavior will affect soil aggregation.

AMF appear to be the most important fungal mediator of soil aggregation due to: a) they represent a dominant soil component accounting for $30 \%$ of whole of soil microbial biomass (Rillig et al., 1999; Olsson, 1999); b) carbon supply resources for living are coming from the root photosynthates in comparison with saprobic fungi which depend on limiting carbon substrates available in the bulk soil and c) there is some evidence that grazers prefer saprobic than mycorrhizal hyphae (Klironomos and Kendrick, 1996) perhaps as a thing of taste resulting in a longer resilience in the soil. As a consequence, AMF appear as one of the most important components in describing biotic influences on soil aggregation. However, AMF exert a strong influence at the scale of macroaggregates $(>250 \mu \mathrm{m})$ in comparison with bacteria and archaea which would be expected to influence the formation and 
stabilization of microaggregates in a more direct way (Rillig and Mummey, 2006). Recently, a new factor and perhaps with greater incidence in soil aggregation was discovered and described by Wright and Upadhyaya (1996) named glomalin which is copiously produced by AMF.

\section{Glomalin}

In recent years it has been described a glycoprotein produced by arbuscular mycorrhizal fungi with a strong cementing capacity of soil particles (Wright and Upadhyaya, 1996; 1998; Rillig et al., 2002; Rillig 2004). Prior to 1996, the influences of AMF in aggregation were not clearly understood and the sources of carbon compounds involved in aggregate stabilization were not known in spite of early reports of Gupta and Germida (1988), Miller and Jastrow (1990) and Haynes and Swift (1990) who suggested the possibility that AMF was involved in soil aggregation but not showing clear evidences on that.

It is now known that glomalin is present in large amounts in soils which is indeed a distinct component of soil organic matter. This is a glycoprotein from Glomales which is the taxonomic genera to which AMF belong (Wright and Upadhyaya, 1996). Axenic cultures show that glomalin, originally present in AMF wall hyphae in a $80 \%$ according Driver et al., (2005) and secreted into the environment in a minor proportion (Rillig and Mummey, 2006), is accumulated in air-water interface (Haddad and Sarkar, 2003). Several studies have shown that glomalin, aggregate stability and soil management are linked (Wright et al., 2007). However, some recent studies do not show such close relationships (Pietrowski et al., 2004).

Glomalin is currently quantified from soil following an operational definition as glomalin-related soil protein (GRSP; Rillig 2004). The main detection tool is a monoclonal antibody (MAb32B11), raised originally against crushed AMF spores
(Wright and Upadhyaya, 1996). The extraction of glomalin from plant hyphae and soils is extremely drastic. In fact, it is the severity of the extraction conditions that clearly demonstrates its uncommonly high stability. Glomalin is very difficult to solubilize and it is resistant to most chemical used in routine and characterization methods (Wright and Upadhyaya, 1996). For this reason is though that glomalin is lost in humin fraction when applying the traditional method for soil humic compounds fractionation (Nichols Wright, 2005) but our research group have not found significant amounts of glomalin in humin fractions from Chilean andisols and ultisols (Borie et al., unpublished). The basic extraction method of glomalin involves the use of a citrate buffer at neutral or slight alkaline $\mathrm{pH}$ at high temperature. It has been postulated two glomalin fractions which differ in extraction conditions from soils. The easily extractable glomalin (EEG) is determinated autoclaving $1 \mathrm{~g}$ of soil mixed with $20 \mathrm{mM}$ citrate at $\mathrm{pH} 7.0$ for $30-60$ $\min$. The solution containing solubilized glomalin is separated by centrifugation at $10000 \mathrm{x} g$ for $10 \mathrm{~min}$. Total glomalin (TG) is determined by an exhaustive extracction with $50 \mathrm{mM}$ citrate solution at $\mathrm{pH} 8.0$ for $60 \mathrm{~min}$ in autoclave. In each fraction the protein is quantified in a spectrophotometer using the Bradford assay. Table 1 shows the correlation coefficients for EEG and TG on several properties among then soil aggregation in 37 different soils according Wright and Upadhyaya (1998). Until now, all papers related to glomalin, including those from different soil types from Chile, show high relationships between $\mathrm{TG}$ and $\%$ soil $\mathrm{C}$ and TG and EEG (Borie et al., 2000). However, we have not found close relationships between water stable soil aggregates (\%) and glomalin content in an Andisoil $(\mathrm{r}=0.26)$ and a Mollisol $(\mathrm{r}=0.11)$ in comparison with an Alfisol $(\mathrm{r}=0.51)$ or an Ultisol ( $\mathrm{r}=0.96)$ (Fig. 1). 
14 Arbuscular mycorrhizal fungi, Borie et al.

Table 1. Correlation coefficients for fractions of glomalin, $\% \mathrm{C}$ in soil aggregates, and aggregate stability (Wright and Upadhyaya, 1998).

Cuadro 1. Coeficientes de correlación para fracciones de glomalina, \% C en agregados del suelo y estabilidad de agregados (Wright and Upadhyaya, 1998).

\begin{tabular}{llll}
\hline & $\% \mathrm{C}$ & $\mathrm{EEG}$ & $\mathrm{TG}$ \\
\hline EEG & $0.49^{* *}$ & & \\
TG & $0.61^{* * *}$ & $0.94^{* * *}$ & \\
Aggregate stability & $0.65^{* * *}$ & $0.69^{* * *}$ & $0.70^{* * *}$ \\
\hline
\end{tabular}

** and $* * *$ denote significance at $\mathrm{p}<0.1$ and $\mathrm{p}<0.01$, respectively.

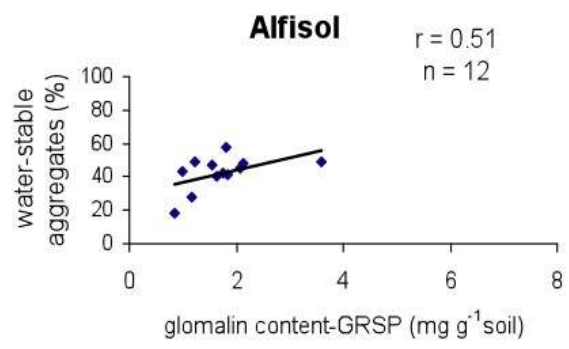

Mollisol

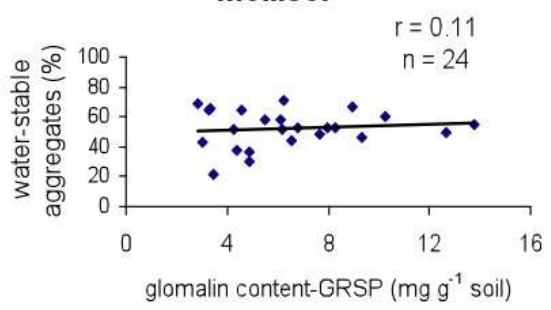

Andisol

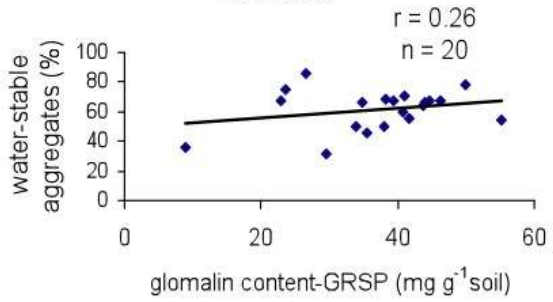

Ultisol

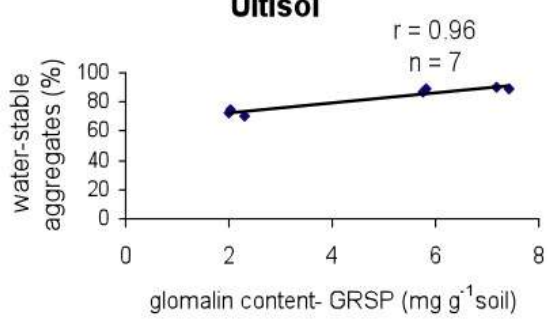

Figure 1: Relationship between glomalin content-GRSP and water-stable aggregates in different soils from Chile.

Figura 1: Relación entre contenido de glomalina-GRSP y agregados estables al agua en diferentes suelos de Chile. 


\section{Soil management and aggregation}

Soil structure can be significantly modified through management practices. In this regard, management practices including tillage methods, residue management, amendment application, soil fertility and crop rotation, among others, can have and enormous influence on soil aggregation and its stability.

Tillage disrupts soil aggregates, compact the subsoil and disturb plant and animal communities leaving a decrease in soil organic matter, CEC, microbial and faunal activities. Furthermore, root and fungal networks are disrupted decreasing the stability of soil aggregates and favoring leaching, losses of nutrients and erosion. Moreover, tillage affects negatively AM fungal mycelia length (Castillo et al., 2006) and also the production of glomalin (Borie et al., 2006) both promoting agents of soil aggregation. The intensity and timing of tillage will determine the extent to which the negative effect on soil aggregation can be occurs.

The addition of compost to soil improves soil structure and lowers the bulk density. Composting materials can increase macroaggregation and rhizospheric aggregate stability. The effects of compost additions on soil structure may be shortlived although these effects are generally positive on structural properties (Debosz et al. 2002). It is expected to find a better soil structure in soils under organic agriculture than in soils with conventional agricultural managements.

The complexities of fertilizers and other amendments on chemical, physical and biological soil properties results on variable effects on soil aggregation. In general, fertilizer application increases soil aggregation through an improvement of microbial and faunal activities. Nitrogen and $\mathrm{P}$ fertilizers added to unfertile soils such as those poor in available $\mathrm{P}$ increase mycorrhizal activity as well as insoluble sources of phosphate (like rock phosphate) does. On the opposite, soluble P sources decrease mycorrhizal colonization specially in fertile $\mathrm{P}$ soils.

On the other hand, the aggregate dynamics vary among different crops, crop rotations and cover crops (Bronick and Lal, 2005). The influence of different crops is according to their chemical composition and root tending to be short-lived under conventional tillage regimes, (Chan and Heenan, 1996). Cover crops increase $\mathrm{C}$ inputs, $\mathrm{CEC}$, soil aggregate stability and may enhance microbial biomass. The influence of crops and crop rotation is important on soil aggregation due to plant roots and their rhizospheric effects. Roots enmesh, realign soil particles and release exudates, which result in physical, chemical and biological alterations that influence soil aggregation (Bronick and Lal, 2005). Aggregation tends to increase with increasing root length density, microbial association and glomalin, among other effects (Rillig et al., 2002). Aggregate stability is greater in rizosphere soil tha non-rizosphere soil (Caravac et al., 2002) due to an increased rhizodeposition, root density, root turnover, hyphal growth, microbial biomass, all of them which directly or indirectly are influencing in maintaining particles together. In a recent paper, Pietrowski et al. (2004) have tested the effects of specific plant-fungus combinations on aggregate stability studying whether hyphal length and root biomass determine its stabilization, predicting whether fungi producing more hyphae, and or plants with higher root biomasses would better stabilize soils structure. They used nine plant species and five fungus species. The results showed that AMF with greater extraradical mycelium production were represented by the Gigasporaceae and plants of high root biomass by grasses. Unfortunately, in this study, the main related hypothesis to find an "specialist" AMF fungus which promote water stable aggregates independent of plant host, was not tested. Until now, the better is to use a cocktail of AMF in eroded soil or for application in soil restoration. 


\section{CONCLUSIONS}

Soil structure stability is strongly influenced by the nature and content of soil organic matter. Land use and management practices influencing SOM will be determinant in soil aggregation. Root and fungal hyphae are among the most important biotic factors, if not the most important agents in soil aggregate stabilization. Given that the importance of soil aggregation to the functioning in the ecosystems and the role played by AMF in this context, it is surprising the lack of studies in connection with this topic. Last years we have done some efforts for studying the relationships between SOM and microbial activity including AMF in aggregation of soils in southern Chile. However, we are aware that more studies are needed for obtaining a better understanding of processes governing the stability of soil aggregates in our volcanic soils. We expect that in vitro glomalin production will be an important tool to face this challenge.

\section{AKNOWLEDGEMENTS}

Financial support of Fondecyt 1060372 is acknowledged. We thank Dr. Francisco Matus from Universidad de La Frontera for its critical comments on early version of the manuscript.

\section{REFERENCES}

AGUILERA, S.M., BORIE, G., GALINDO, G., PEIRANO, P. 1997. Organic matter in volcanic soils in Chile. Chemical and Biochemical characterization. Commun. Soil Sci. Plant Anal. 28: 899-912.

BORIE, F., BAREA, J.M. 1985. Occurrence of lipid-P in volcanic ash derived soils of Chile. Agrochimica 28: 317-324.
BORIE, F., RUBIO, R., MORALES, A., CASTILLO, C. 2000. Relación entre densidad de hifas de hongos micorrizógenos arbusculares y producción de glomalina con las características físicas y químicas de suelos bajo cero labranza. Rev. Chil. Hist.Nat. 73: 749-756.

BORIE, F., RUBIO, R., ROUANET,J.L, MORALES, A., BORIE, G., ROJAS,C. 2006. Effects of tillage systems on soil charactectics, glomalin and mycorrhizal propagules in a Chilean Ultisol. Soil Till. Res. 88: 253261.

BRONICK, C.J., LAL, R. 2005. Soil structure and management : a review. Geoderma 124: 3-22.

CARAVACA, F., HERNÁNDEZ, T., GARCÍA, C., ROLDÁN, A. 2002. Improvement of rhizosphere aggregate stability of afforested semiarid plant species subjected to mycorrhizal inoculation and compost addition. Geoderma 108: 133-144.

CASTILLO, C. G., RUBIO, R., ROUANET, J.L, BORIE, F. 2006. Early effects of tillage and crop rotation on arbuscular mycorrhizal fungal propagules in an Ultisol. Biol. Fert. Soils 43: 83-92.

CHAN, K.Y., HEENAN, D.P. 1996. The influence of crop rotation on soil structure and soil physical properties under conventional tillage. Soil Till. Res. 37: 113-125.

CHENU, C., LE BISSONNAIS, Y., ARROUAYS, D. 2000. Organic matter influence on clay wettability and soil aggregate stability. Soil Sci. Soc. Am.J. 64: 1479-1486.

CHOROVER, J., AMISTADI, M.K., CHADWICK, O.A. 2004. Surface charge evolution of mineral-organic complexes during pedogenesis in Hawaiian basalt. Geochim. Cosmochim. Ac. 68: 4859-4876. 
DEBOSZ, K., PETERSEN, S.O., KURE, L.K., AMBUS,P. 2002. Evaluating effects of sewage sludge and household compost on soil physical, chemical and microbiological properties. Appl. Soil Ecol. 19: 237-248.

DEGENS, B.P. 1997. Macro-aggregation of soils by biological bonding and binding mechanisms and the factors affecting these : a review. Austr. J. Soil Res.35: 431-459.

DIGNAC, M. F., BAHARI, H., RUMPEL, C., RASSE, D. P., BARDOUX, G., BALESDENT, J., GIRARDIN, C. CHENU, C., MARIOTTI, A. 2005. Carbon- 13 natural abundance as a tool to study the dynamics of lignin monomers in soil: an appraisal at the Closeaux experimental field (France). Geoderma 128: 3-17.

DRIVER, J.D., HOLBEN, W., RILLIG, M.C. 2005. Characterization of glomalin as a hyphal wall component of arbuscular mycorrhizal fungi. Soil Biol. Biochem. 37:101-106.

EVINER, V.T., CHAPIN, F.S. 2002. The influence of plant species, fertilization and elevated $\mathrm{CO}_{2}$ on soil aggregate stability. Plant Soil 246: 211-219.

GUPTA,. S.R., GERMIDA, J.J.1988. Distribution of microbial biomass and its activity in different soil aggregate sizes as affected by cultivation. Soil Biol. Biochem. 20: 777-786.

HADDAD, M.J., SARKAR, D. 2003. Glomalin, a newly discovered component of soil organic matter. Part II. Relationship with soil properties. Environm. Geosc. 10: 99-106.

HAYNES, R.J., SWIFT, R.S. 1990. Stability of soil aggregates in relation to organic constituents and soil water content. J.Soil Sci. 41: 73-83.

JASTROW, J.D. 1996. Soil aggregate formation and the accrual of particulate and mineral- associated organic matter. Soil Biol. Biochem. 28: 665-676.
KLIRONOMOS, J.N., KENDRICK, W. B. 1996. Palatability of microfungi to soil arthropods in relation to the functioning of arbuscular mycorrhizae. Biol. Fert. Soils 21: 43-52.

MATUS, F., AMIGO, X., KRISTIANSEN, S.A. 2006. Aluminium stabilization controls organic carbon levels in Chilean volcanic soils. Geoderma 132: $158-168$.

MILLER, R.M., JASTROW, J.D. 1990. Hierarchy of roots and mycorrhizal fungal interactions with soil aggregation. Soil Biol. Biochem. 5: 579-584.

NICHOLS, K., WRIGHT, S. 2005. Comparison of glomalin and humic acids in eight native US soils. Soil Sci. 170: 985-997.

OADES, J.M. 1988. The retention of organic matter in soils. Biogeochemistry 5: 35-70.

OLSSON, P.A., THINGSTRUP, I., JAKOBSEN, I., BAATH,F. 1999. Estimation of the biomass of arbuscular mycorrhizal fungi in a linseed field. Soil Biol.Biochem. 31: 1879-1887.

PIETROWSKI, J.S., DENICH, T., KLIRONOMOS, J.N., GRAM., J.M., RILLIG, M.C. 2004. The effects of arbuscular mycorrhizas on soil aggregation depend on the interaction between plant and fungal species. New Phytol. 164: 365-373.

RILLIG, M.C., WRIGHT, SF., ALLEN, M.E, FIELD, C.B. 1999. Rise in carbon dioxide changes soil structure. Nature 440-628-630.

RILLIG, M.C., MUMMEY, D.L. 2006. Mycorrhizas and soil structure. New Phytol. 171: 41-53.

RILLIG, M.C., WRIGHT, S.F., EVINER,V.2002. The role of arbuscular mycorrhizal fungi and glomalin in soil aggregation: comparing effects of five plant species. Plant Soil 238: 325-333. 
18 Arbuscular mycorrhizal fungi, Borie et al.

RILlig, M.C. 2004. Arbuscular mycorrhizae, glomalin, and soil aggregation. Can J.Soil Sci. 84: 355363.

SCHULTEN, H.R., LEINWEBER, P. 2000. New insights into organic-mineral particles: composition, properties, and models of molecular structure. Biol. Fert. Soils 30: 399-432

SIX, J., ELLIOT, E.T., PAUSTIAN, K. 1999. Aggregate and soil organic matter dynamics under conventional and no-tillage systems. Soil Sci. Soc. Am.J. 63: 1350-1358.

SIX, J., ELLIOT, E.T., PAUSTIAN, K. 2000. Soil macroaggregate turnover and microaggregate formation.: a mechanism of $\mathrm{C}$ sequestration under no-tillage agriculture. Soil Biol Biochem. 32: 2013-2099.

TISDALL, J.M., SMITH, S.E., RENGASAMIN, P. 1997. Aggregation of soil by fungal hypahe. Austr.J. Soil Res. 35: 55-60.

VAN DER HEIJDEN, M.G.A., KLIRONOMOS, J.N., URSIC, M., MOUTOGLIS, P., STREITWOLFENGEL, R., BOLLER, T., WIEMKEN, A., SANDERS, I.R. 1998. Mycorrhizal fungal diversity determines plant biodiversity, ecosystem variability, and productivity. Nature: 396-69-72.
WRIGHT, S.F., UPADHYAYA, A. 1996. Extraction of an abundant and unusual protein from soil and comparison with hyphal protein of arbuscular mycorrhizal fungi. Plant Soil 198: 97 107.

WRIGHT, S.F., UPADHYAYA, A. 1998. A survey of soils for aggregate stability and glomalin, a glycoprotein produced by hyphae of arbuscular mycorrhizal fungi. Soil Sci. 16: 575-586.

WRIGHT, S.F., GREEN,V.S., CAVIGELLI, M.A. 2007. Glomalin in aggregate size classes from three different farming systems. Soil Till. Res. 94: 546-549.

ZHANG, X.C, NORTON, L.D. 2002. Effect of exchangeable $\mathrm{Mg}$ on saturated hydraulic conductivity, disaggregation and clay dispersion of disturbed soils. J. Hydrol. 160: 194-205. 